\title{
Overview of the current status of buffel grass dieback
}

\author{
S. Makiela $\mathrm{B}, \mathrm{C}, \mathrm{D}$ and K. M. Harrower ${ }^{\mathrm{A}, \mathrm{B}}$ \\ A Department of Living Systems, Central Queensland University, Rockhampton, Qld 4702, Australia. \\ ${ }^{B}$ Centre for Plant and Water Science, Central Queensland University, Rockhampton, QId 4702, Australia. \\ CPresent address: Institute for Sustainable Regional Development, Central Queensland University, \\ Rockhampton, Qld 4702, Australia. \\ DCorresponding author. Email: s.makiela@cqu.edu.au
}

\begin{abstract}
Over at least the last decade in Australia a condition known as buffel grass dieback has been a major concern to graziers who utilise this grass in improved pastures due to its fodder value for cattle. This is the first full description of the dieback condition of buffel grass (Cenchrus ciliaris L.), including morphological and histological symptoms. The cause of this condition still remains unknown.
\end{abstract}

\section{Introduction}

Buffel grass (Cenchrus ciliaris L.) is a tufted tussock grass that grows to about $0.4-1.0 \mathrm{~m}$ tall. Since its introduction to Australia, about 10 varieties of buffel grass have been released for commercial plantings; the most common varieties are Biloela, Gayndah and American. Buffel grass is a naturalised species that occurs in about 5 million hectares across northern Australia on grazing land and park land. This species is extensively used in improved pastures.

Buffel grass dieback (BGD) is a little-studied condition for which there is a paucity of information, with remarkably few scientific references. Manifested as dead patches in buffel grass pastures in areas of Central Queensland (CQ), BGD has been a cause of growing concern to graziers since 1993 (Graham and Conway 1998). BGD has the potential to destroy large areas of improved pasture and is currently estimated to affect hundreds of hectares in the CQ area (Fig. 1). Dead and diseased patches in paddocks may reach up to $60 \mathrm{~m}$ in diameter and substantial areas of even very large (120 ha) paddocks may lose buffel by convergence of adjacent patches. Recolonisation of affected areas by other less palatable plant species renders those areas less useful for grazing. Recent unpublished observations revealed that self-sown buffel seedlings in an affected patch succumb before reaching the third leaf stage. Of the three most common cultivars of buffel grass, American buffel is the most widely affected, whereas the Biloela cultivar appears to be resistant.

\section{Condition description}

Symptoms of BGD present as a reddening of the leaves starting from the tip of a leaf and progressively moving towards the ligule. The red symptoms range from bright red to dark red to bronze (RHSPCC red group 45: A, B; 46: A, B; greyed-orange group 166: A; 177: A) (The Royal Horticultural Society 2001). Symptoms first appear on the older leaves. The next oldest leaves then show symptoms, and so on, with the youngest leaf showing symptoms last (Fig. 2). The tillers follow the same pattern, regardless of whether the symptoms on the primary shoot had progressed past the point at which the tiller was produced. The amount of time taken from new growth to the appearance of the red symptoms seems to be proportional to the amount of rainfall promoting new growth. That is, the more rain, the longer it takes for the symptoms to develop. The amount of subsequent rainfall seems to influence the time it takes for plants to succumb to the condition. That is, when there is adequate water and lush growth plants grow faster than the spread of the condition. When plants become water stressed, the condition overtakes growth and the plants succumb (Makiela and Harrower 2003).

Symptomatic leaves do not always have a clear red-green boundary (Fig. 3). Occasionally, BGD symptoms progress faster down one-half of the leaf. Red symptoms are invariably more vivid on the adaxial (upper) surface of the leaves than on the abaxial (lower) surface. Roots of affected plants appear stunted compared with those of unaffected plants (Fig. 4). Roots of affected plants often display soft, darker and ovoid sunken regions.

The BGD condition appears to become dormant as buffel grass becomes dormant during dry seasons. That is, if the dieback condition kills the plant before the onset of dormancy, clearly no new shoots are produced subsequent to a rainfall event. However, if dormancy occurs before the plant succumbs to the condition, new shoots are produced after rain, and the cycle repeats with symptoms first appearing in the oldest leaf.

Observations showed that BGD patches were roughly circular and ranged from $2 \mathrm{~m}$ to over $60 \mathrm{~m}$ diameter (Fig. 5). Adjacent patches often coalesced and further enlarged. Symptoms first appeared on plants at the periphery of an existing patch, where during the last cycle the plants had become dormant before succumbing to the condition. Symptoms progressively moved outwards from the periphery of the patch, at a rate of approximately $5 \mathrm{~cm}$ per week. Patch spread was irregular and did not correspond with soil compaction or land slope, though the condition may spread more rapidly downhill, perhaps somehow due to runoff. 


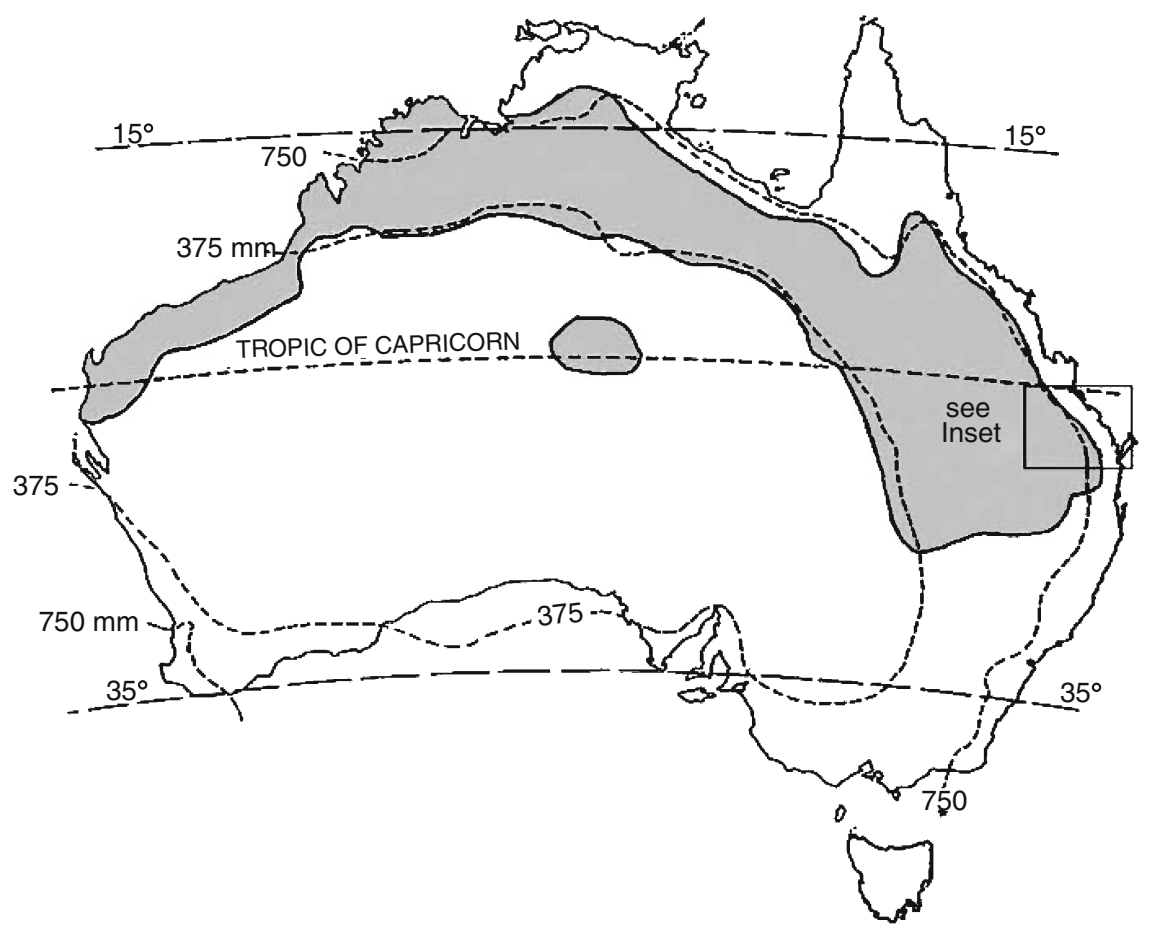

Inset

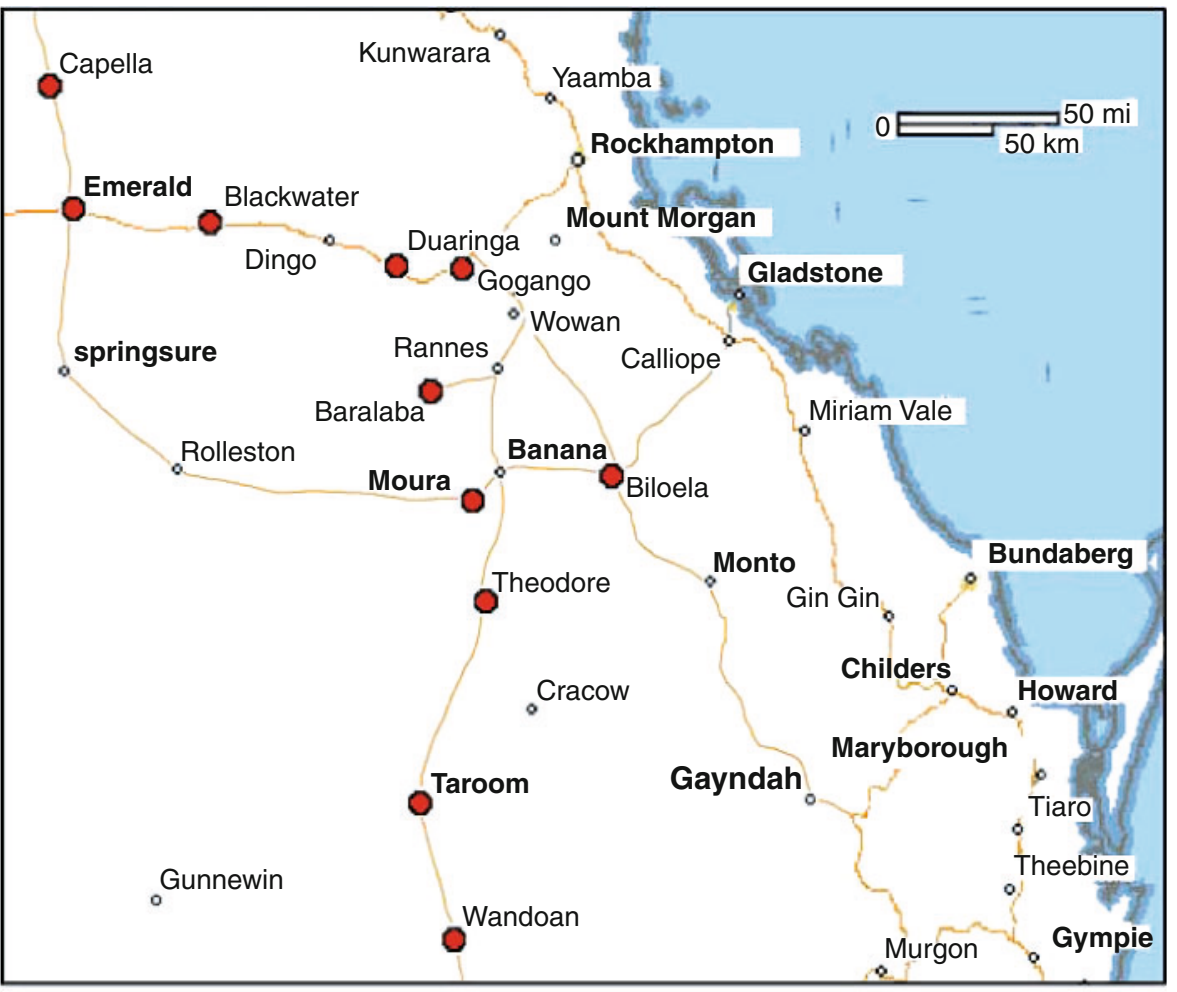

O = Reported areas with Buffel Grass Dieback

Fig. 1. Colonisation (shaded area) of buffel grass (Cenchrus ciliaris) across northern Australia and reported areas with buffel grass dieback in central Queensland (inset). 

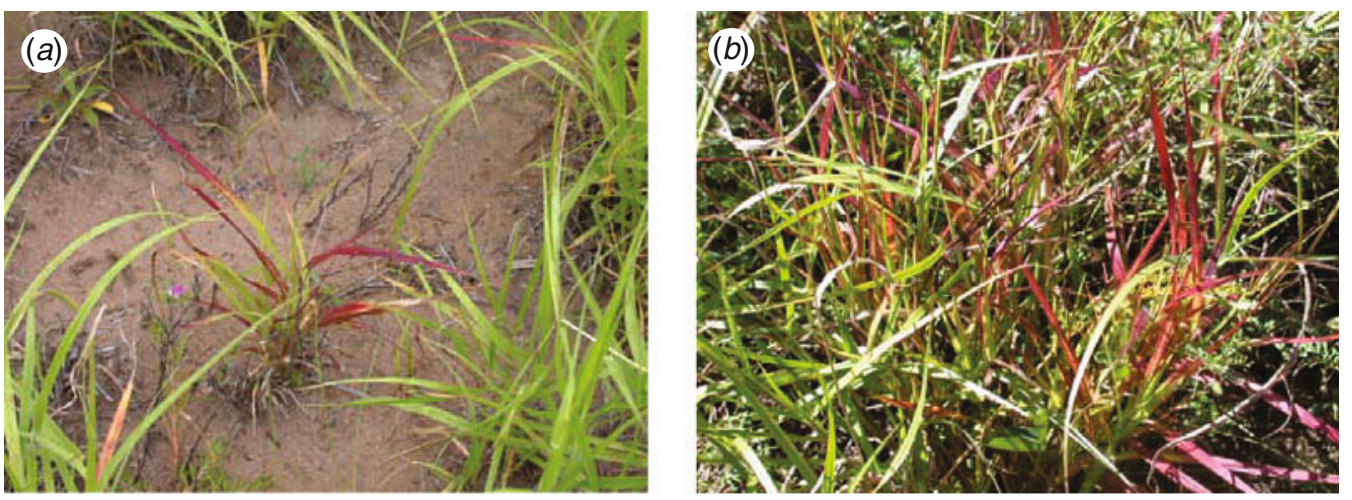

Fig. 2. Buffel grass (Cenchrus ciliaris) plants affected with the dieback condition: (a) young plant and (b) buffel grass tussock.

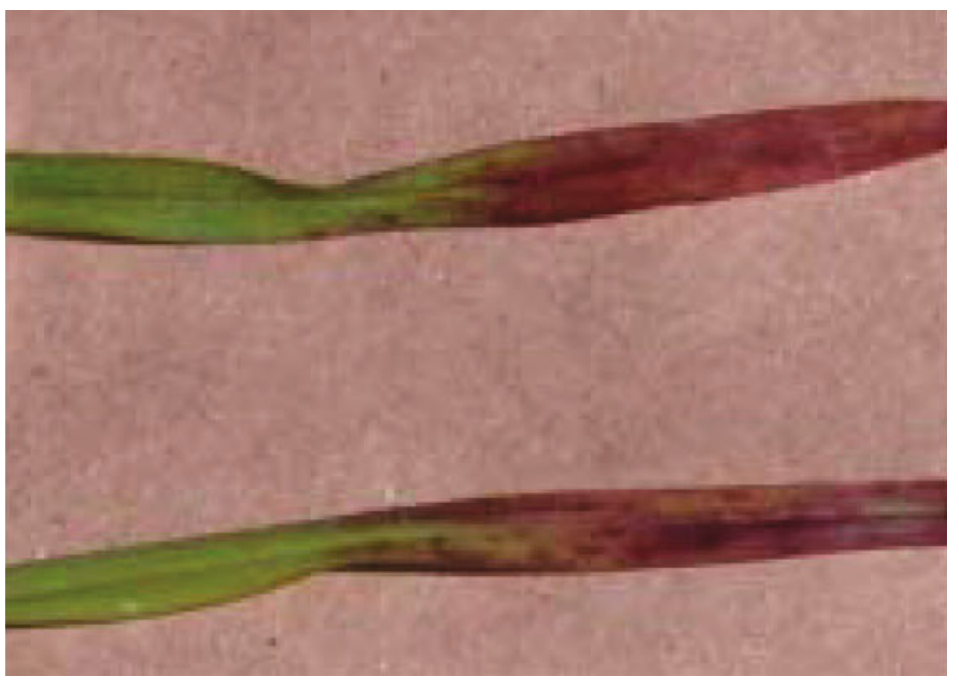

Fig. 3. Red-green margin leaf symptom of buffel grass (Cenchrus ciliaris) affected with buffel grass dieback.
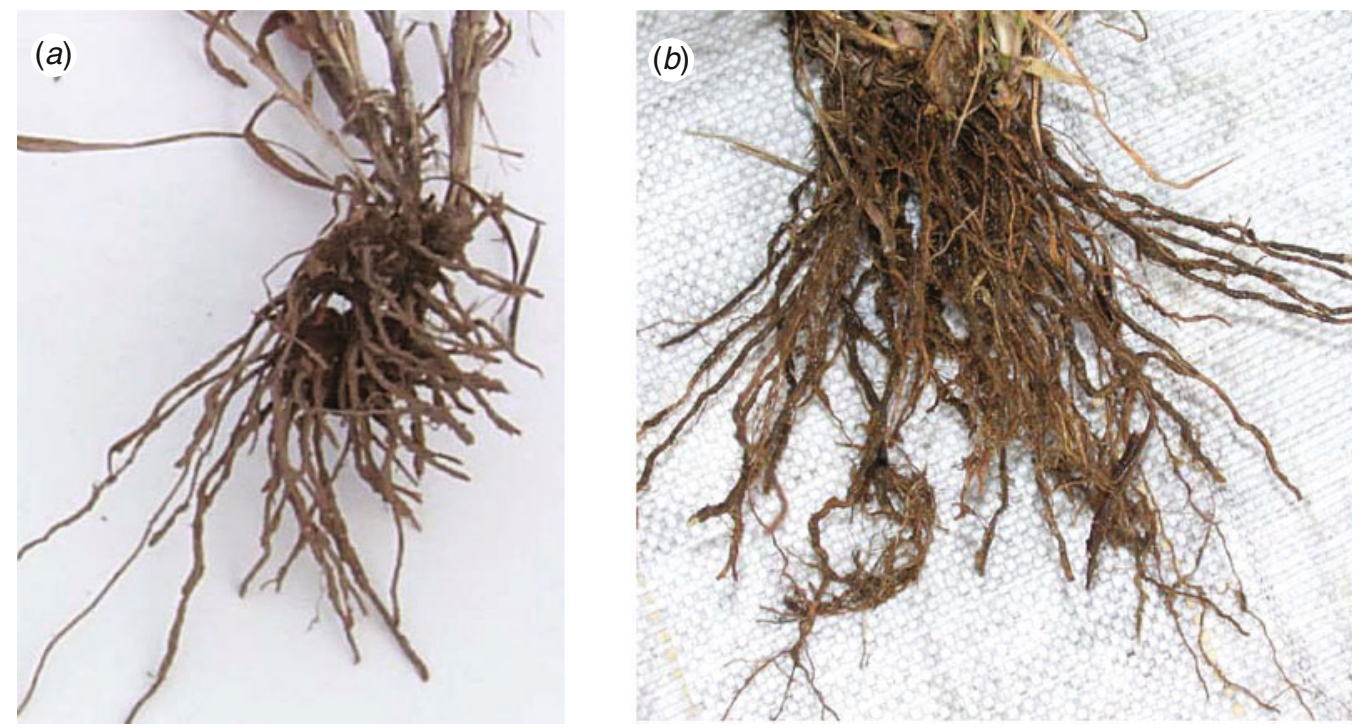

Fig. 4. Roots of buffel grass (Cenchrus ciliaris) (a) affected with buffel grass dieback and (b) unaffected. 


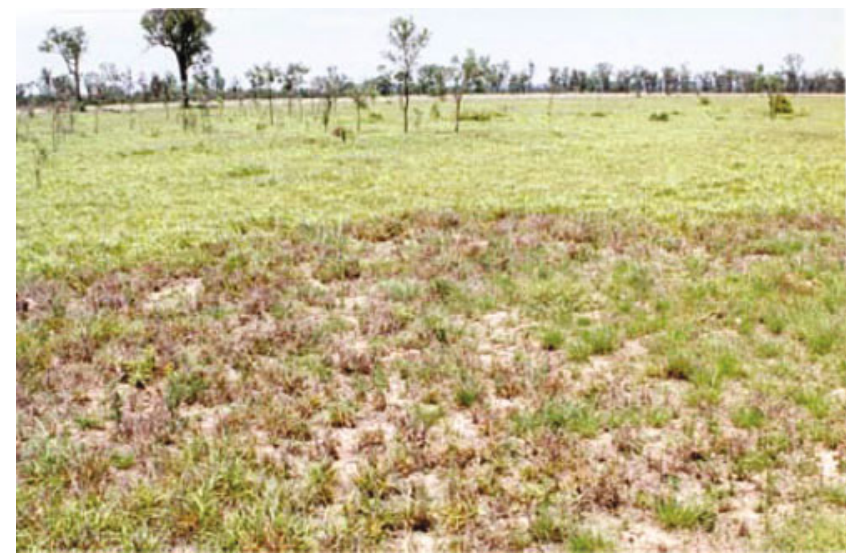

Fig. 5. Patch of buffel grass (Cenchrus ciliaris) affected with buffel grass dieback.

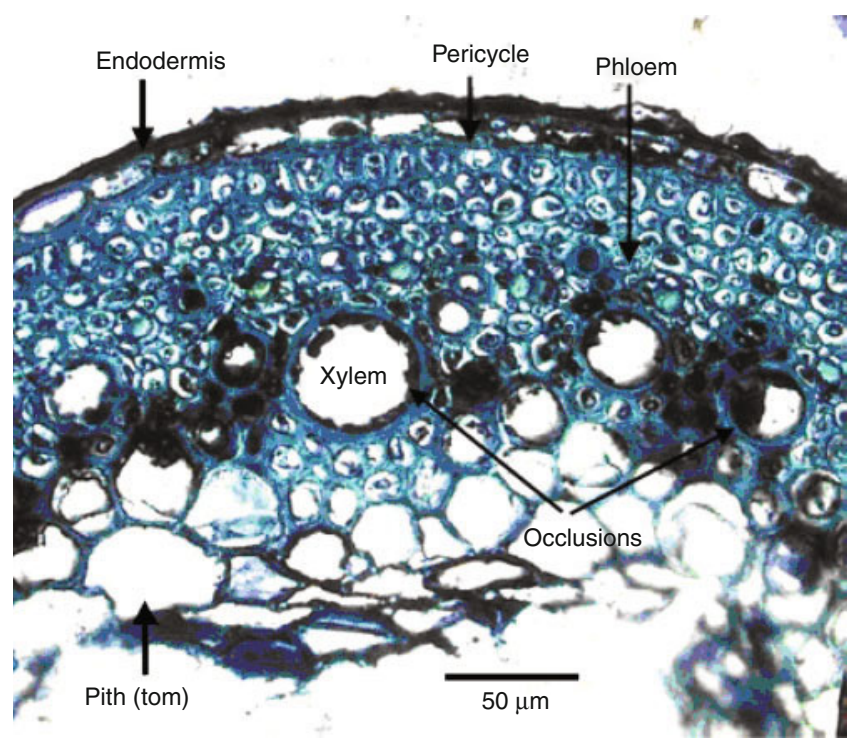

Fig. 6. Transverse section of a BGD-affected root of buffel grass (Cenchrus ciliaris) showing cellular damage and xylem occlusions. The cortex was missing, as was typical of these root sections.

\section{Effect of BGD on buffel grass plants}

The BGD condition was found to have several effects on buffel grass plants. However, whether these were directly produced by the causal agent(s) of BGD or whether they were secondary symptoms is uncertain.

BGD-affected plants, heavily affected but not yet dying, weighed approximately two-thirds that of unaffected plants (data not shown). They were noticeably shorter and had shorter leaves and internodes, with the difference in height attributed to internode length. BGD-affected plants also had fewer tillers than unaffected plants of the same age. Although the numbers of leaves per tiller were the same as in unaffected plants, the overall result was a decreased amount of foliage available for grazing, thereby decreasing productivity of livestock. In fact, the loss of productivity was proportional to the area and intensity of affected plants, since cattle had been observed to
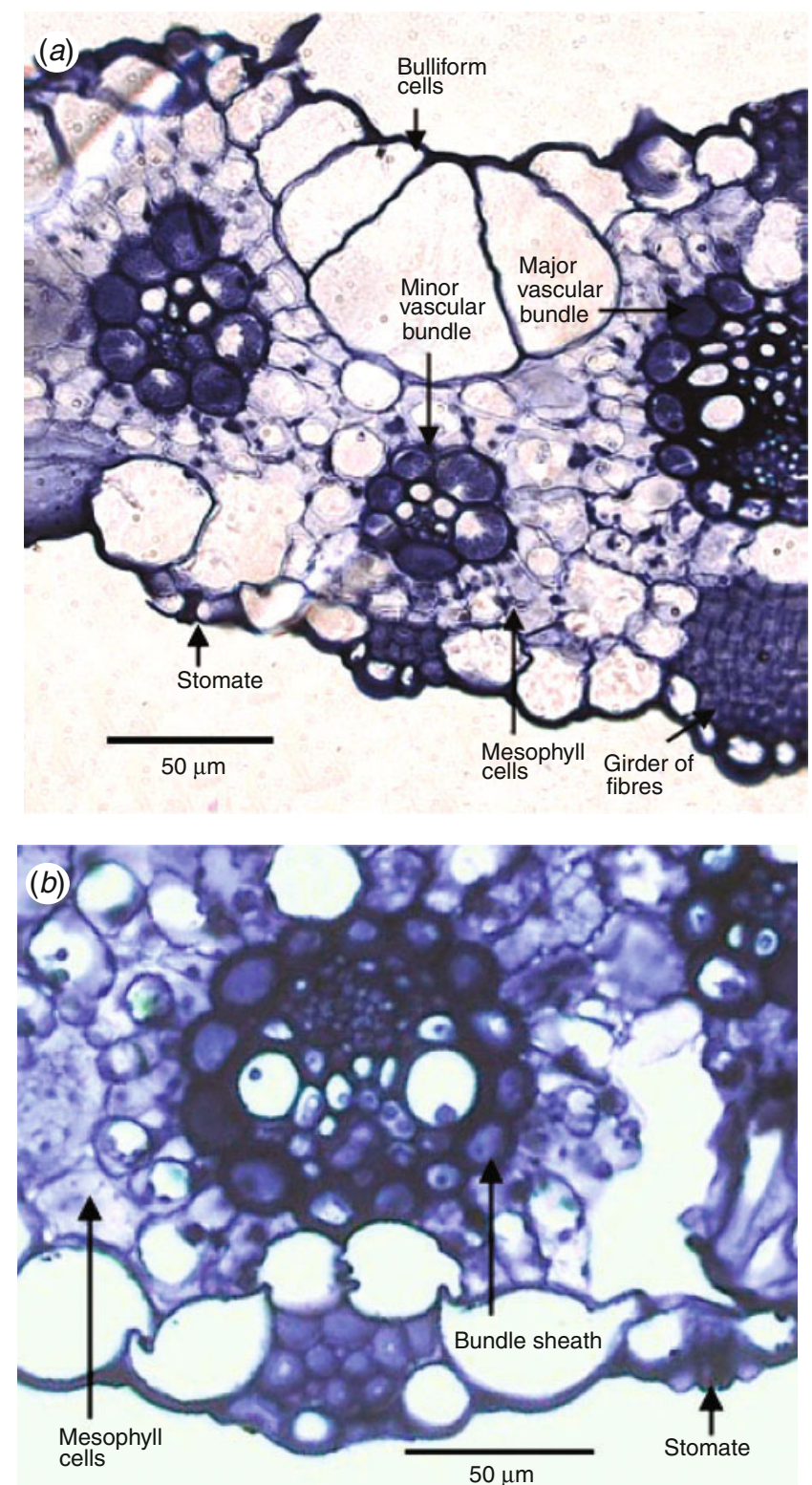

Fig. 7. Cross-section of (a) healthy buffel grass (Cenchrus ciliaris) leaf and $(b)$ leaf affected with buffel grass dieback.

selectively graze unaffected plants (Webb, primary producer, pers. comm).

BGD-affected plants had fewer seed heads, shorter seed fascicles and a higher proportion of non-viable embryos compared with unaffected plants. Therefore, not only did BGDaffected plants succumb and die, but there were fewer seedlings to replace them. This could have detrimental consequences for the sustainability of an improved pasture.

At the cellular level, there was no discernable difference in cell size between BGD-affected plants and unaffected plants in either roots or leaves. However, the roots of BGD-affected plants were more damaged at the cellular level, with the cortex mostly absent and the mesophyll cells disrupted (Fig. 6). 
The bulliform and mesophyll cells of BGD-affected leaves were more irregular in shape compared with those of unaffected plant leaves. The bundle sheath cells of BGD-affected leaves appeared disrupted, with chloroplasts not in their usual alignment. There also seemed to be a breakdown of chloroplasts (Fig. 7).

There was no discernible difference in the phloem vessels of BGD-affected and unaffected plants, both in the roots and the leaves. However, the xylem of both roots and leaves of BGD affected plants was partially occluded by structures tentatively identified as tyloses (Fig. 7b). These structures could also have been local accumulations of phenols or polyphenols and/or the remnants of partially decomposed cells. These occlusions were more severe in the roots than in the leaves. These bodies are usually a sign of pathogen infection, whether bacterial, fungal or viral (Musetti et al. 2000). However, the histology work detected no bacterial or fungal pathogens. Similarly, pathology testing, comprising root, leaf and soil isolations, with the resulting cultures being inoculated onto healthy plant material, yielded no microbiological causal agent (data not shown).

Leaf pigment data (data not shown) concurred with the premise of a breakdown of chloroplasts. Red symptomatic leaves had lower concentrations of chlorophylls $a$ and $b$ compared with those of green leaves on the same plant. Red symptomatic leaves also had higher concentrations of anthocyanins and carotenoids. It appears that in red symptomatic leaves chlorophylls were being destroyed and anthocyanins were being excessively produced.

Whether these symptoms and effects are a direct result of the causal agent(s) or whether they are secondary symptoms resulting from physiological causes is difficult to determine. For example, are the stunted plants a result of the stunted roots? This is feasible since stunted, rotted roots would interfere with the water and nutrient uptake and transport. The stunting may also be a result of xylem occlusions or tyloses, since these would also interfere with water and nutrient supply.

The BGD-affected plants were stunted, but histological work showed there was no discernible size difference between cells. Consequently, it can be concluded that BGD influences cell production, not cell expansion, although it is possible that it affects cell elongation since longitudinal sections were not performed. This implies the possible involvement of plant growth regulators.

Overall, it seems that the causal agent(s) of BGD directly affects the roots and subsequently the vascular tissues, with a possible mode of transport through the xylem. There is probable interference with the synthesis of plant growth regulators and the uptake and transport of water and nutrients, resulting in the secondary symptoms of stunting, red leaves, less seed production and overall plant stress.

To date, the causal agent(s) of BGD remains unknown and Koch's Postulates have never been satisfied.

\section{References}

Graham TWG, Conway M (1998) Some sick buffel. TGS News and Views 14, 6 .

Makiela S, Harrower KM (2003) Buffel grass (Cenchrus ciliaris) dieback in Central Queensland. Agricultural Science 16, 34-36.

Musetti R, Favali MA, Pressacco L (2000) Histopathology and polyphenol content in plants infected by phytoplasmas. Cytobios 102, 133-147.

The Royal Horticultural Society (2001) 'Royal Horticultural Society Plant Colour Chart.' (The Royal Horticultural Society: London)

Manuscript received 14 January 2008, accepted 6 February 2008 